\title{
Penerapan 2 SLS GM M-A B pada Persamaan Simultan Data Panel Dinamis untuk Pemodelan Pertumbuhan Ekonomi Indonesia sebagai Islamic Country
}

\author{
Arya Fendha Ibnu Shina \\ Institut Teknologi Sepuluh Nopember (ITS) Surabaya \\ E-mail: aryafendhaibnushina@yahoo.co.id
}

\begin{abstract}
A bstract
Indonesia is an islamic country that still has problems in economics such as unemployment and poverty. Stability and economic growth are expected to overcome these problems. Two-way relationship between unemployment and economic growth can be summarized in a system of simultaneous equation. Two directions relationship of mutual influence can be summarized in a system of simultaneous equations. Economic variables are dynamic; the value is influenced by value of variable itself in the past and also the value of other variables. In a dynamic panel data model there is a lag of the dependent variable that causes the OLS estimates can be biased and inconsistent. A rellano-B ond GMM with optimal weight produces parameter estimate which is unbiased, consistent, and efficient. From this study we can conclude that there is a simultaneous relationship between economic growth and unemployment. If economic growth increases $1 \%$, it will cause the unemployment decrease to $0.956 \%$ in short-term and $0.988 \%$ in shortterm. On the other hand, if unemployment increases $1 \%$, it will cause a slowdown in economics to $0.465 \%$ and $0.615 \%$ for the long term.
\end{abstract}

Key Words : A rellano and Bond estimator, GMM, Simultanous Equation.

\section{A bstrak}

Indonesia merupakan negara islam yang masih memiliki permasalahan di bidang ekonomi, yaitu pengangguran dan kemiskinan. Pertumbuhan dan stabilitas ekonomi diharapkan mampu mengatasi permasalahan tersebut. Hubungan dua arah antara pengangguran dengan pertumbuhan ekonomi dapat terangkum di dalam satu sistem persamaan simultan. Variabel-variabel ekonomi bersifat dinamis dimana nilainya dipengaruhi oleh nilai variabel itu sendiri di masa lalu dan juga nilai variabel lain. Pada model data panel dinamis terdapat lag variabel dependen yang menyebabkan estimasi OLS 
menjadi bias dan tidak konsisten. GM M A rellano-B ond dengan bobot optimal menghasilkan taksiran parameter yang tak bias, konsisten, dan efisien. Dari penelitian ini dapat disimpulkan bahwa terdapat hubungan yang simultan antara pertumbuhan ekonomi dan pengangguran. Jika terjadi peningkatan pertumbuhan ekonomi sebesar $1 \%$ maka akan menyebabkan penurunan tingkat pengangguran secara jangka pendek sebesar 0,956\% dan secara jangka panjang sebesar $0,988 \%$. Di sisi lain jika terjadi peningkatan tingkat pengangguran sebesar $1 \%$ maka akan menyebabkan perlambatan pertumbuhan ekonomi secara jangka pendek sebesar $0,465 \%$ dan secara jangka panjang sebesar $0,615 \%$.

Kata Kunci : Estimator Arellano dan Bond, GMM, Persamaan Simultan

\section{Pendahuluan}

Indonesia merupakan negara islam yang masih memiliki permasalahan di bidang ekonomi diantaranya adalah pengangguran dan kemiskinan. Di sisi lain, pengangguran dan kemiskinan ini merupakan dua hal yang dapat mendekatkan umat manusia pada kekufuran. $\mathrm{Hal}$ tersebut sesuai dengan sabda Nabi M uhammad SAW, "K efakiran (kemiskinan) itu mendekatkan pada kekufuran"(HR. M uttafaq A laih).

Pertumbuhan dan stabilitas ekonomi diharapkan mampu mengatasi kemiskinan dan pengangguran. Pertumbuhan ekonomi Indonesia mengalami perkembangan yang fluktuatif setelah terjadi krisis ekonomi nasional pada akhir abad ke-20an. Pada periode 2007 sampai dengan 2012 perekonomian Indonesia tumbuh di atas 5\%, kecuali pada tahun 2009 yang hanya tumbuh sebesar 4,63\% akibat krisis global. Pertumbuhan ekonomi merupakan salah satu indikator keberhasilan perekonomian suatu negara. Pertumbuhan ekonomi diukur menggunakan Produk Domestik Regional Bruto (PDRB). PDRB adalah jumlah nilai tambah barang dan jasa yang dihasilkan dari seluruh kegiatan pekonomian di seluruh daerah selama satu tahun. PDRB memuat sembilan sektor, yaitu : pertanian, pertambangan, industri, listrik gas dan air, bangunan, perdagangan, transportasi dan angkutan, lembaga keuangan, serta jasa-jasa.

Tujuan kebijakan di bidang makroekonomi diantaranya adalah peningkatan pertumbuhan ekonomi dan tingkat pengangguran yang rendah. Pertumbuhan ekonomi dan tingkat pengangguran yang rendah merupakan indikator perekonomian yang saling terkait (Indriani, 2008). 
A gama islam mengajarkan umatnya agar tidak menganggur, karena pengangguran berdampak kepada kemiskinan yang akan mendekatkan manusia pada kekufuran. Namun pada kenyataannya, tingkat pengangguran di negara-negara yang penduduknya mayoritas islam masih sangat tinggi. M eningkatnya pemahaman mengenai dampak buruk dari pengangguran diharapkan dapat menigkatkan motivasi untuk bekerja lebih serius. Dari kaca mata makroekonomi, pengangguran akan mengakibatkan tidak optimalnya peningkatan pertumbuhan ekonomi. Hal ini disebabkan oleh tidak termanfaatkannya sebagian dari faktor produksi yaitu tenaga kerja. Hal ini senada seperti yang diungkapkan Okun (1962) dalam (Iswanto, 2013) yang menyatakan bahwa terdapat hubungan negatif antara jumlah pengangguran dengan tingkat pertumbuhan ekonomi suatu negara, hubungan ini kemudian disebut sebagai Hukum Okun (Okun's Law). Untuk menyederhanakan analisis, Okun mengasumsikan bahwa tingkat pengangguran dapat berfungsi sebagai pengganti variabel dari jumlah tenaga kerja yang digunakan dalam perekonomian. Mankiw (2010) mengatakan bahwa adanya pertumbuhan PDB yang mendekati $2 \%$ akan mengurangi pengangguran sebesar $1 \%$.

Pertumbuhan ekonomi yang semakin meningkat berarti pula meningkatnya produksi barang dan jasa, sehingga diperlukan tenaga kerja semakin banyak untuk memproduksi barang dan jasa. Tenaga kerja merupakan faktor produksi yang sangat penting disamping modal, sumber daya alam, dan teknologi karena tenaga kerja berperan penting di dalam pembangunan yaitu sebagai pelaku pembangunan. M asalah ketenagakerjaan ini dapat menimbulkan masalah-masalah baru baik di bidang ekonomi maupun nonekonomi. Jika tingkat penyerapan tenaga kerja tinggi, maka tingkat pengangguran akan menurun dan berdampak pada semakin menurunnya tingkat kemiskinan. U paya meningkatkan pertumbuhan ekonomi guna menurunkan tingkat pengangguran dan tingkat kemiskinan adalah saling berkaitan, sehingga dibutuhkan suatu metode statistika yang dapat menghasilkan model untuk mengakomodasi hubungan antara pertumbuhan ekonomi dan beberapa variabel yang memiliki pengaruh secara simultan, yaitu pengangguran dan kemiskinan.

Model persamaan tunggal mengabaikan interdependensi antara variabel ekonomi. Dalam kasus ekonomi, sering ditemui variabel yang me- 
miliki hubungan dua arah. Hubungan dua arah yang saling mempengaruhi ini dapat terangkum di dalam satu sistem persamaan simultan. Setiawan dan Kusrini (2010) mengatakan bahwa hampir semua pendekatan dalam makroekonomi memiliki sifat simultan.

Dalam melakukan penelitian mengenai pertumbuhan ekonomi suatu wilayah tidak cukup hanya dengan menggunakan data cross section karena perlu dilakukan observasi perilaku unit penelitian pada berbagai periode waktu. Data yang merupakan gabungan antara data cross section dan data time series disebut data panel. Hsiao (2003) dan Klevmarken (1989) dalam (Baltagi, 2005) mengatakan bahwa ada beberapa keuntungan menggunakan data panel, yaitu data bersifat heterogen, lebih informatif, bervariasi, derajat bebas lebih besar, lebih efisien, lebih unggul dalam mempelajari perubahan dinamis, lebih dapat mendeteksi dan mengukur pengaruh-pengaruh yang tidak terobservasi pada data cross section murni dan time series murni, dan meminimalisasi bias. Penelitian yang menggunakan metode persamaan simultan data panel dilakukan oleh Jonaidi (2012) untuk menganalisis hubungan pertumbuhan ekonomi dan kemiskinan di Indonesia menggunakan metode estimasi 2 SLS (two stage least square) dan ILS (Indirect Least Square). M ustaqim (2009) menganalisis pengaruh pertumbuhan ekonomi terhadap penyerapan tenaga kerja di provinsi Jawa Tengah menggunakan pendekatan persamaan simultan dengan fixed effect model dengan metode estimasi 2SLS (two stage least square). A nwar dan N guyen (2010) meneliti hubungan simultan antara pertumbuhan ekonomi dan investasi luar negeri (Foreign Direct Investment/ FDI) di Vietnam menggunakan metode estimasi Generalized M ethod of M oment (GMM). Penelitian-penetian tersebut menggunakan model data panel statis.

B anyak variabel ekonomi yang bersifat dinamis artinya nilai suatu variabel dipengaruhi oleh nilai variabel Iain dan juga nilai variabel yang bersangkutan di masa lalu. Dengan demikian dibutuhkan model data panel dinamis. Model data panel dinamis juga dapat digunakan untuk menganalisa dampak jangka pendek dan jangka panjang dari suatu kebijakan ekonomi. Pada model data panel dinamis terdapat lag dari variabel dependen yang berkedudukan sebagai variabel eksplanatori. Variabel ini berkorelasi dengan error. Dengan demikian estimasi menggunakan OLS akan menghasilkan 
estimator yang bias dan tidak konsisten. Untuk mengatasi hal tersebut Anderson dan Hsiao (1982) menyarankan untuk menggunakan metode estimasi variabel instrumen, yakni dengan menginstrumenkan variabel yang berkorelasi dengan error. Kelemahan dari metode ini adalah menghasilkan estimator yang tak bias dan konsisten, namun belum efisien. Metode variabel instrumen Anderson dan Hsiao ini selanjutnya dikembangkan oleh Arellano dan Bond (1991). Arellano dan Bond (1991) menggunakan prinsip GMM untuk mengestimasi parameter pada model data panel dinamis. Metode estimasi ini selanjutnya disebut sebagai GMM Arellano-Bond. Metode estimasi GMM Arellano-Bond menghasilkan estimator yang tak bias, konsisten, dan efisien. Arellano dan Bond (1991) kemudian mengaplikasikan metode ini untuk memodelkan ketenagakerjaan di Inggris pada 140 perusahaan dalam periode 1979-1984 menggunakan model panel dinamis.

Penelitian-penelitian terdahulu yang disebutkan di depan memiliki kelemahan yaitu hanya menggunakan persamaan simultan data panel statis dan model panel dinamis dengan persamaan tunggal. Oleh karena itu, pada penelitian ini akan digunakan persamaan simultan data panel dinamis menggunakan metode GMM Arellano-Bond untuk memodelkan pertumbuhan ekonomi, pengangguran, dan kemiskinan di Indonesia.

\section{Regresi data panel}

Salah satu struktur data yang sering digunakan dalam studi ekonomi adalah data panel, data yang memiliki struktur time series dan cross section. Dengan kata lain, data panel merupakan data dari beberapa individu atau objek yang diamati dalam periode suatu periode waktu. Jika dimiliki sebanyak $N$ individu dimana $i=1,2,3, \ldots, N$ dalam $T$ waktu dimana $t=1,2,3, \ldots, T$ maka observsi total yang dimiliki adalah sebanyak $N_{x} T$.

Model regresi linier data panel dengan $K$ buah variabel prediktor pada pengamatan ke- $i$ dan waktu ke- $t$, direpresentasikan sebagai berikut:

$y_{i, t}=\alpha+\boldsymbol{x}_{\boldsymbol{i}, \boldsymbol{t}}^{\prime} \boldsymbol{\beta}+u_{i, t} ; \quad i=1,2, \ldots, N ; t=1,2, \ldots T$

Dimana :

$y_{i, t}=$ variabel dependen yang merupakan unit cross section ke- $i$ untuk periode ke- $t$ 
$\alpha=$ skalar

$x^{\prime}{ }_{i, t}=$ vektor dari variabel independen berukuran $1 \times \mathrm{K}$

$\beta=$ vektor konstanta yang berukuran $K \times 1$

$u_{i, t}=$ error

Secara umum model regresi linier data panel yang sering digunakan adalah model regresi data panel komponen error satu arah (one-way error component regression model), dimana error terdiri dari :

$u_{i, t}=e_{i}+v_{i, t}$

$e_{i}$ adalah komponen error spesifik individu dan $v_{i, t}$ merupakan komponen error yang bersifat umum (Baltagi,2005).

\section{Regresi data panel dinamis}

Model data panel dinamis sering digunakan dalam menggambarkan hubungan antar variabel-variabel ekonomi. Model panel dinamis digambarkan dalam persamaan di bawah ini :

$y_{i, t}=\delta y_{i, t-1}+\boldsymbol{x}_{i, t}^{\prime} \boldsymbol{\beta}+u_{i, t} i=1,2, \ldots, N ; t=1,2, \ldots T$

dengan $\delta$ merupakan skalar, $x_{i, t}$, adalah dari variabel independen berukuran $1 \mathrm{x} K$, dan $\beta$ adalah vektor konstanta yang berukuran $K$ x 1 . Diasumsikan $u_{i t}$ merupakan komponen error satu arah (one-way error component regression model) dan diasumsikan $e_{i} \sim \operatorname{IIDN}\left(0, \sigma_{e}^{2}\right)$ dan $v_{i, t} \sim \operatorname{IIDN}\left(0, \sigma_{v}^{2}\right)$. Lai, dkk (2008) mengatakan bahwa dalam model regresi panel dinamis koefisian $\beta$ juga merupakan efek jangka pendek dari perubahan $x_{i, t}$ sedangkan $\left(\frac{\beta}{(1-\delta)}\right)$ merupakan efek jangka panjang dari perubahan $x_{i, t}$

Apabila $y_{i, t}$ adalah fungsi dari $u_{i, t}$ maka sebagai akibatnya $y_{i, t}$ juga merupakan fungsi dari $u_{i, t}$. Dengan kata lain, regressor pada sisi kanan (endogen eksplanatori) $y_{i, t-1}$ berkorelasi dengan $u_{i, t}$. Penggunakan metode estimasi panel statis seperti OLS pada model persamaan panel dinamis akan bias dan tidak konsisten (Baltagi, 2005). 


\section{Metode instrumen variabel anderson-hsiao}

Berikut ini dituliskan model regresi panel dinamis sederhana, yaitu model data panel dinamis dengan lag dari variabel dependen sebagai satusatunya variabel eksplanatori (variabel endogen eksplanatori) di dalam model.

$y_{\mathrm{i}, \mathrm{t}}=\delta y_{\mathrm{i}, \mathrm{t}-1}+u_{\mathrm{it}} \quad i=1,2, \ldots, \mathrm{N} ; \quad t=1,2, \ldots T$

dengan komponen error satu arah.

Untuk mengatasi masalah utama dalam regresi panel dinamis yaitu regressor pada sisi kanan $y_{i, t-1}$ berkorelasi dengan $u_{i, t}$, Anderson dan Hsiao (1982) mengusulkan metode estimasi untuk regresi panel dinamis sederhana yang kemudian disebut sebagai metode Instrumental Variabel Anderson dan Hsiao.

Baltagi (2005) mengatakan bahwa untuk menghilangkan efek individual, maka dilakukan first-difference. Dengan demikian, persamaan (4) menjadi,

$$
\begin{array}{r}
\left(y_{\mathrm{i}, \mathrm{t}}-y_{\mathrm{i}, \mathrm{t}-\mathrm{t}}\right)=\delta\left(y_{\mathrm{i}, \mathrm{t}-1}-y_{\mathrm{i}, \mathrm{t}-2}\right)+\left(v_{\mathrm{i}, \mathrm{t}}-\mathrm{v}_{\mathrm{i}, \mathrm{t}-1}\right) ; \\
i=1,2, \ldots, N ; t=1,2, \ldots T
\end{array}
$$

Model pada persamaan (5) jika ditulis dalam bentuk vektor matriks, adalah sebagai berikut :

$\Delta y_{\mathrm{i}}=\delta \Delta \mathrm{y}_{\mathrm{i}, \mathrm{t}-1}+\Delta \mathrm{v}_{\mathrm{i}} ; \quad i=1,2, \ldots, N$

Dapat ditulis juga menjadi

$$
\Delta v_{\mathrm{i}}=\Delta \mathrm{y}-\Delta \mathrm{y}_{\mathrm{i}, \mathrm{t}-1}
$$

Pada persamaan (6) masih terlihat jelas bahwa variabel-variabel $\Delta \boldsymbol{y}_{i,-1}$ masih berkorelasi dengan $\Delta \boldsymbol{v}_{i}$. Sehingga diperlukan variabel instrumen.

Matriks instrumen yaitu matriks yang berisi variabel-variabel instrumen dan telah memenuhi syarat-syarat sebagai variabel instrumen, yaitu berkorelasi dengan $\Delta \mathbf{y}_{i,-1}$ namun tidak berkorelasi dengan $\Delta \mathbf{v}_{\mathrm{i}}$. Menurut Anderson dan Hsiao (1982) variabel instrumen yang valid untuk $\boldsymbol{\Delta} \boldsymbol{y}_{i,-1}$ adalah $\boldsymbol{y}_{i,-2}$ atau $\boldsymbol{\Delta} \boldsymbol{y}_{i,-2}$. Selanjutnya, Anderson dan Hsiao (1982) menggunakan 
variabel instrumen $\boldsymbol{y}_{i,-2}$ dahulu. Matriks instrumen yang dibentuk oleh $\boldsymbol{y}_{i,-2}$ didefinisikan sebagai $\mathbf{Z}_{\mathrm{i}}$, dimana

$$
\boldsymbol{Z}_{i}=\left[\begin{array}{c}
y_{i, 1} \\
y_{i, 2} \\
\vdots \\
y_{i, T-2}
\end{array}\right]
$$

Matriks instrumen kemudian dikaliakan pada persamaan (7) selanjutkan dicari nilai ekspektasinya.

$$
\begin{gathered}
\boldsymbol{Z}_{i}^{\prime} \boldsymbol{\Delta} \boldsymbol{v}_{i}=\boldsymbol{Z}_{i}^{\prime} \Delta \boldsymbol{y}_{i}-\delta \boldsymbol{Z}_{i}^{\prime} \boldsymbol{\Delta} \boldsymbol{y}_{i,-1} \\
\boldsymbol{E}\left(\boldsymbol{Z}_{i}^{\prime} \boldsymbol{\Delta} \boldsymbol{v}_{i}\right)=E\left(\boldsymbol{Z}_{i}^{\prime} \Delta \boldsymbol{y}_{i}\right)-\delta E\left(\boldsymbol{Z}_{i}^{\prime} \boldsymbol{\Delta} \boldsymbol{y}_{i,-1}\right)
\end{gathered}
$$

Karena $\boldsymbol{E}\left(\boldsymbol{Z}_{i}^{\prime} \boldsymbol{\Delta} \boldsymbol{v}_{i}\right)=0$ (syarat $\mathbf{Z}_{\mathrm{i}}$ sebagai matriks instrumen), maka

$$
\widehat{\delta}=\left[N^{-1} \sum_{i=1}^{N} \boldsymbol{Z}_{i}^{\prime} \boldsymbol{\Delta} \boldsymbol{y}_{i,-1}\right]^{-1}\left[N^{-1} \sum_{i=1}^{N} \boldsymbol{Z}_{i}^{\prime} \boldsymbol{\Delta} \boldsymbol{y}_{i}\right]
$$

Persamaan (8) adalah hasil estimasi dengan metode Instrumental Variabel Anderson dan Hsiao Hasil estimasi ini tak bias dan konsisten.

Langkah-langkah estimasi parameter menggunakan variabel instrumen $\boldsymbol{\Delta} \boldsymbol{y}_{i,-2}$, sama seperti ketika menggunakan $\boldsymbol{y}_{i,-2}$, namun menggunakan matriks instrumen Nismawati (2010).

$$
\boldsymbol{Z}_{i}=\left[\begin{array}{c}
y_{i, 2}-y_{i, 1} \\
y_{i, 3}-y_{i, 2} \\
\vdots \\
y_{i, T-2}-y_{i, T-3}
\end{array}\right]
$$

\section{Generalized Moment Methode Arellano-Bond}

Baltagi (2005) mengatakan bahwa hasil estimasi Instrumental Variabel Anderson dan Hsiao menghasilkan variansi yang lebih besar dibandingkan GMM Arellano dan Bond. Dengan demikian hasil estimasi GMM Arellano dan Bond lebih efisien dibandingkan Instrumental Variabel 
Anderson dan Hsiao. Seperti yang dijelaskan di atas bahwa metode Instrumental variabel Anderson dan Hsiao menghasilkan taksiran yang tak bias, konsisten, namun tidak efisien.

Pada metode GMM Arellano dan Bond, matriks instrumen yang digunakan adalah

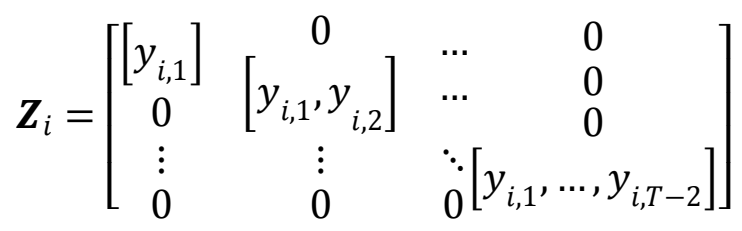

Estimasi parameter oleh Arellano dan Bond menggunakan prinsip GMM untuk mendapatkan taksiran yang konsisten.

Taksiran GMM untuk $\delta$ adalah suatu taksiran $(\widehat{\delta})$ yang meminimumkan $J(\hat{\delta})$.

$$
\begin{aligned}
& \widehat{\delta}=\left[\left(N^{-1} \sum_{i=1}^{N} \boldsymbol{\Delta} \boldsymbol{y}_{i,-1}{ }^{\prime} \boldsymbol{Z}_{i}\right) \widehat{\boldsymbol{W}}\left(N^{-1} \sum_{i=1}^{N} \boldsymbol{Z}_{i}^{\prime} \boldsymbol{\Delta} \boldsymbol{y}_{i,-1}\right)\right]^{-1} \\
& {\left[\left(N^{-1} \sum_{i=1}^{N} \boldsymbol{\Delta y}_{i,-1}{ }^{\prime} \boldsymbol{Z}_{i}\right) \widehat{\boldsymbol{W}}\left(N^{-1} \sum_{i=1}^{N} \boldsymbol{Z}_{i}^{\prime} \Delta \boldsymbol{y}_{i}\right)\right] }
\end{aligned}
$$

Estimator $\widehat{\delta}$ merupakan estimator yang konsisten tidak tergantung bagaimana pemilihan bobot $\widehat{W}$.

Pemilihan $\widehat{\boldsymbol{W}}$ tidak akan mempengaruhi kekonsistenan taksiran, namun dengan memilih $\widehat{\boldsymbol{W}}$ yang optimal akan menghasilkan taksiran yang efisien. Arellano dan Bond (1991) mengusulkan bobot $\widehat{\boldsymbol{W}}$ yang optimal sebagai berikut :

$$
\widehat{W}=\widehat{\Lambda}^{-1}
$$

dengan

$$
\widehat{\Lambda}=N^{-1} \sum_{i=1}^{N} Z_{i}^{\prime} \Delta v_{i} \Delta v_{i}{ }^{\prime} Z_{i}
$$


Sehingga dihasilkan,

$$
\begin{gathered}
\widehat{\delta}=\left[\left(N^{-1} \sum_{i=1}^{N} \boldsymbol{\Delta} \boldsymbol{y}_{i,-1}{ }^{\prime} \boldsymbol{Z}_{i}\right) \widehat{\boldsymbol{\Lambda}}^{-\mathbf{1}}\left(N^{-1} \sum_{i=1}^{N} \boldsymbol{Z}_{i}^{\prime} \boldsymbol{\Delta} \boldsymbol{y}_{i,-1}\right)\right]^{-1} \\
{\left[\left(N^{-1} \sum_{i=1}^{N} \boldsymbol{\Delta} \boldsymbol{y}_{i,-1}{ }^{\prime} \boldsymbol{Z}_{i}\right) \widehat{\boldsymbol{\Lambda}}^{-\mathbf{1}}\left(N^{-1} \sum_{i=1}^{N} \boldsymbol{Z}_{i}^{\prime} \Delta \boldsymbol{y}_{i}\right)\right]}
\end{gathered}
$$

(Nismawati, 2010)

\section{Model persamaan simultan}

M odel persamaan simultan adalah model dimana var dependen pada suatu persamaan bisa menjadi var independen di persamaan lain. Jumlah persamaan adalah sama dengan jumlah variabel yang bernilai untuk dijelaskan. Variabel yang bernilai untuk dijelaskan ini disebut variabel endogen. Variabel lainnya adalah variabel yang berkontribusi menjelaskan model, variabel ini disebut variabel predetermined (ditetapkan mula-mula). Variabel predetermined ini terdiri dari dua variabel, yaitu variabel eksogen dan variabel endogen lembam (lagged endogenous). Model persamaan simultan dalam susunan matrikx adalah sebagai berikut:

$$
\left[\begin{array}{cccc}
\alpha_{11} & \alpha_{12} & \ldots & \alpha_{1 M} \\
\alpha_{21} & \alpha_{22} & \ldots & \alpha_{2 M} \\
\vdots & \vdots & \ddots & \vdots \\
\alpha_{M 1} & \alpha_{M 2} & \ldots & \alpha_{M M}
\end{array}\right]\left[\begin{array}{c}
Y_{1 i} \\
Y_{2 i} \\
\vdots \\
Y_{M i}
\end{array}\right]+\left[\begin{array}{cccc}
\beta_{11} & \beta_{12} & \ldots & \beta_{1 K} \\
\beta_{21} & \hat{\mathrm{a}}_{22} & \ldots & \beta_{2 K} \\
\vdots & \vdots & \ddots & \vdots \\
\beta_{M 1} & \beta_{M 2} & \ldots & \beta_{M K}
\end{array}\right]\left[\begin{array}{c}
X_{1 i} \\
X_{2 i} \\
\vdots \\
X_{K i}
\end{array}\right]=\left[\begin{array}{c}
\mu_{1 i} \\
\mu_{2 i} \\
\vdots \\
\mu_{M i}
\end{array}\right]
$$

selanjutnya dapat diringkas menjadi,

$$
\boldsymbol{\Gamma} \boldsymbol{Y}_{i}+\boldsymbol{B} \boldsymbol{X}_{i}=\boldsymbol{\mu}_{i}, \quad i=1,2, \ldots, N
$$

Dengan $\Gamma$ adalah matrik koefisien $\alpha$ dengan ukuran $M \times M, B$ adalah matrik koefisien $\beta$ dengan ukuran $M x K, Y_{i}$ adalah vektor $M$ variabel endogen dengan ukuran $M \times 1, X_{i}$ adalah vektor $K$ variabel eksogen dengan ukuran $\mathrm{K} \times 1, \mu_{\imath}$ adalah matrik structural disturbance untuk t waktu. Model pada persamaan (9) merupakan model lengkap yang secara umum dapat 
diselesaikan dengan model reduced form. Model reduced form ditulis sebagai berikut:

$$
\left[\begin{array}{c}
Y_{1 i} \\
Y_{2 i} \\
\vdots \\
Y_{M i}
\end{array}\right]=\left[\begin{array}{cccc}
\pi_{11} & \pi_{12} & \ldots & \pi_{1 K} \\
\pi_{21} & \pi_{22} & \ldots & \pi_{2 K} \\
\vdots & \vdots & \ddots & \vdots \\
\pi_{M 1} & \pi_{M 2} & \ldots & \pi_{M K}
\end{array}\right]\left[\begin{array}{c}
X_{1 i} \\
X_{2 i} \\
\vdots \\
X_{K i}
\end{array}\right]+\left[\begin{array}{c}
v_{1 i} \\
v_{2 i} \\
\vdots \\
v_{M i}
\end{array}\right]
$$

dapat pula ditulis menjadi:

$$
\boldsymbol{Y}_{i}=\boldsymbol{\Pi} \boldsymbol{X}_{i}+\boldsymbol{v}_{i}, \quad i=1,2, \ldots, N
$$

\section{Identifikasi Model Persamaan Simultan}

Kaidah yang sering digunakan untuk menentukan identifikasi suatu sistem persamaan simultan adalah dengan order conditions. Untuk memahami order conditions, maka perlu dipahami beberapa notasi berikut :

1. $M$ = banyaknya variabel endogen dalam model,

2. $m$ = banyaknya variabel endogen dalam sebuah persamaan tertentu,

3. $K=$ banyaknya variabel predetermined di dalam model,

4. $k$ = banyaknya variabel predetermined di dalam sebuah persamaan tertentu.

Identifikasi suatu persamaan simultan dengan kaidah order conditions memberikan informasi sebuah persamaan teridentifikasi secara tepat (just identified/exactly identified) atau teridentifikasi secara berlebihan (overidentified). Jika $K-k=m-1$ maka dikatakan bahwa persamaan tersebut adalah persamaan yang teridentifkasi secara tepat (just identified/ exactly identified), jika $K-k \geq m-1$ maka dikatakan bahwa persamaan tersebut adalah persamaan yang teridentifkasi secaraberlebihan (overidentified).

Variabel endogen dalam persamaan simultan berkorelasi dengan galat (disturbance), maka estimator OLS akan menghasilkan estimator yang bias dan tidak konsisten. Dibutuhkan alternatif metode estimasi yang lain yang disebut metode Two Stage Least Square (2 SLS). 2SLS merupakan penerapan dari OLS dalam dua tahap. Uji kesimultanan (Uji Haussman) dibutuhkan untuk menguji apakah variabel endogen eksplanatori berkorelasi dengan galat (disturbance) atau tidak. 


\section{B eberapa Indikator M akroekonomi}

\section{Produk Domestik Regional Bruto (PDRB)}

Produk Domestik Regional B ruto (PDRB) adalah salah satu indikator yang digunakan untuk mengetahui kondisi perekonomian suatu daerah dalam suatu periode tertentu. PDRB pada dasarnya merupakan jumlah dari nilai tambah yang dihasilkan oleh seluruh unit usaha dalam suatu daerah, atau merupakan jumlah nilai barang dan jasa akhir yang dihasilkan oleh seluruh unit ekonomi pada suatu daerah. PDRB konstan digunakan untuk mengetahui pertumbuhan ekonomi secara riil dari tahun ke tahun atau pertumbuhan ekonomi yang tidak dipengaruhi oleh faktor harga.

\section{Pengangguran}

Pengangguran adalah suatu keadaan di mana seseorang yang tergolong dalam angkatan kerja ingin mendapatkan pekerjaan tetapi belum dapat memperolehnya. $M$ asalah mengenai pengangguran penting untuk dianalisa karena pengangguran dapat menimbulkan gejolak sosial politik yang dapat mengganggu stabilitas ekonomi suatu negara. Menganggur disamping akan memberikan dampak negatif bagi pelakunya secara langsung juga akan berpengaruh pada perekonomian suatu negara secara keseluruhan. Dari kaca mata ekonomi makro, pengangguran akan menyebabkan tidak optimalnya peningkatan pertumbuhan ekonomi disebabkan oleh tidak termanfaatkannya secara maksimal sebagian potensi dari faktor produksi yaitu tenaga kerja. K elompok pengangguran menggantungkan hidup pada orang-orang yang bekerja, dengan demikian tingkat ketergantungan akan menjadi tinggi serta pendapatan perkapota akan menurun.

Tingkat pengangguran dipengaruhi oleh pertumbuhan ekonomi. Hal tersebut senada dengan Mankiw (2010) yang mengatakan bahwa adanya pertumbuhan PDB yang mendekati $2 \%$ akan mengurangi pengangguran sebesar $1 \%$. Penelitian Indriani (2006) menghasilkan kesimpulan bahwa peningkatan pertumbuhan ekonomi akan menurunkan tingkat pengangguran. Dengan adanya peningkatan pertumbuhan ekonomi diharapkan akan meningkatkan ketersediaan lapangan kerja sehingga dapat mengurangi jumlah pengangguran. Lapangan kerja itu sendiri erat kaitannya dengan belanja 
modal (capital expenditure) yang disebut pula belanja pembangunan. B elanja modal adalah pengeluaran pemerintah yang digunakan untuk menambah aset dan kekayaan daerah seperti membangun infrastruktur. K resnanda dan Ernawati (2013) mengatakan bahwa apabila proporsi anggaran belanja modal pemerintah yang lebih besar daripada belanja rutin maka pertumbuhan ekonomi di daerah akan berjalan dengan efektif. Dengan demikian fasilitas pelayanan publik kepada masyarakat pun akan meningkat dan pada akhirnya akan mengurangi pengangguran. Belanja modal itu sendiri terkandung di dalam belanja langsung pemerintah. M elalui alokasi belanja modal yang proporsional, aset dan kekayaan daerah berupa infrastruktur dan fasilitas umum dapat dibangun. A danya infrastruktur yang memadai ini akan menarik investor untuk menanamkan modal. Penanaman modal ini tentunya membuka peluang untuk terciptanya lapangan pekerjaan baru, dengan demikian dapat menekan tingkat pengangguran.

\section{Kemiskinan}

Seseorang dikatakan miskin jika pendapatan atau akses terhadap barang dan jasa relatif rendah dibandingkan dengan rata-rata orang lain. Bagi Indonesia, kemiskinan sudah sejak lama menjadi persoalan yang hingga sekarang belum menunjukkan tanda-tanda akan berakhir. Dengan terjadinya krisis ekonomi tahun 1997 telah mengakibatkan anjloknya pertumbuhan ekonomi Indonesia. Pada tahun 1998 pertumbuhan Indonesia sebesar 13,13\% sedangkan pada tahun 1999 mencapai 1,29\%. Dampak dari krisis ini menyebabkan jumlah penduduk miskin meningkat. Berbagai upaya penanggulangan kemiskinan terus dilakukan pemerintah demi mengeluarkan penduduk miskin dari jurang kemiskinan melalui pertumbuhan ekonomi yang berkualitas dan peningkatan akses terhadap kebutuhan dasar seperti kesehatan dan pendidikan (Iswanto, 2013).

Indonesia sebagai negara islam memiliki jumlah rakyat miskin yang masih banyak. Kemiskinan dapat menyebabkan berbagai masalah sosial seperti kejahatan, kelaparan, rentan penyakit, dan stres. Kemiskinan sangat erat kaitannya dengan penderitaan dan kehinaan. 


\section{Spesifikasi Model}

Spesifikasi model yang dibangun terdiri dari empat model, yaitu model pertumbuhan ekonomi (PDRB), pengangguran (EM), dan kemiskinan (HC). Spesifikasi model yang dibangun tersebut mengacu pada penelitian Anwar dan Nguyen (2010). Tiga model yang dibangun adalah sebagai berikut:

1. Model pertumbuhan ekonomi (PDRB)

$$
\begin{aligned}
P D R B_{i, t}= & O P_{i, t}^{\alpha_{1}} T D G E_{i, t}{ }^{\alpha_{2}} E M_{i, t}{ }^{\alpha_{3}} P D R B_{i, t-1}{ }^{\alpha_{4}} u_{i t} \\
\ln P D R B_{i, t}= & \alpha_{1} \ln O P_{i, t}+\alpha_{2} \ln T D G E_{i, t}+\alpha_{3} \ln E M_{i, t}+\alpha_{4} \ln P D R B_{i, t-1} \\
& \quad+\ln u_{i t}
\end{aligned}
$$

2. Model pengangguran (EM)

$$
\begin{aligned}
E M_{i, t}= & W_{i, t}^{\beta_{1}} D D I_{i, t}^{\beta_{2}} \operatorname{TDGE}_{i, t}^{\beta_{3}} P D R B_{i, t}^{\beta_{4}} E M_{i, t-1}^{\beta_{5}} u_{i t} \\
\ln E M_{i, t}= & \beta_{1} \ln W_{i, t}+\beta_{2} \ln D D I_{i, t}+\beta_{3} \ln T D G E_{i, t} \\
& +\beta_{4} \ln P D R B_{i, t}+\beta_{5} \ln E M_{i, t-1}+\ln u_{i t}
\end{aligned}
$$

3. Model kemiskinan (HC)

$$
\begin{aligned}
& H C_{i, t}=I G_{i, t}^{\gamma_{1}} I H K_{i, t}^{\gamma_{2}} \operatorname{PDRB}_{i, t}^{\gamma_{3}} H C_{i, t-1}^{\gamma_{4}} u_{i t} \\
& \ln H C_{i, t}=\gamma_{1} \ln I G_{i, t}+\gamma_{2} \ln I H K_{i, t}+\gamma_{3} \ln P D R B_{i, t}+\gamma_{4} \ln H C_{i, t-1}+\ln u_{i t}
\end{aligned}
$$

\section{Variabel Penelitian}

Tabel 1.

\begin{tabular}{lll}
\hline Variabel & Nama Variabel & \multicolumn{1}{c}{ Keterangan } \\
\hline PDRB & $\begin{array}{l}\text { Produk Domestik } \\
\text { Regional Bruto }\end{array}$ & $\begin{array}{l}\text { PDRB atas dasar harga konstan } \\
\text { masing-masing provinsi (milyar rupiah) }\end{array}$ \\
\hline EM & Emplyment & $\begin{array}{l}\text { Tingkat Pengangguran terbuka masing- } \\
\text { masing propinsi di Indonesia (persen) }\end{array}$ \\
\hline HC & Head Count & Jumlah penduduk miskin \\
\hline OP & Openess & $\begin{array}{l}\text { Indikator keterbukaan yang didekati } \\
\text { dengan nilai ekspor (juta dollar) }\end{array}$ \\
\hline
\end{tabular}


Penerapan 2 SLS GMM-AB pada Persamaan Simultan Data Panel Dinamis...

\begin{tabular}{lll}
\hline Variabel & Nama Variabel & \multicolumn{1}{c}{ Keterangan } \\
\hline TDGE & $\begin{array}{l}\text { Total Direct } \\
\text { Goverment } \\
\text { Expenditure }\end{array}$ & $\begin{array}{l}\text { Pengeluaran langsung pemerintah } \\
\text { daerah yang terdiri dari belanja } \\
\text { pegawai, belanja modal, dan belanja } \\
\text { barang dan jasa (juta rupiah) }\end{array}$ \\
\hline DDI & $\begin{array}{l}\text { Domestic Direct } \\
\text { Invesment }\end{array}$ & $\begin{array}{l}\text { Penanaman modal dalam negeri (milyar } \\
\text { rupiah) }\end{array}$ \\
\hline IG & Indeks Gini & Indikator distribusi pendapatan \\
\hline W & Wages & Upah Minimum Provinsi (ribu rupiah) \\
\hline$i$ & Indeks Harga & Indikator penghit ungan inflasi (persen) \\
\hline$t$ & Konsumen & Provinsi-provinsi di Indonesia \\
\hline$u_{i t}$ & Identity & Periode waktu \\
\hline$l n$ & Error & \\
\hline
\end{tabular}

\section{Estimasi Parameter Persamaan Simultan Data Panel Dinamis GMM Arellano Bond}

Langkah pertama yang harus dilakukan untuk menentukan metode estimasi pada model persamaan simultan adalah identifikasi persamaan. Jika masing persamaan struktural teridentifikasi secara tepat atau berlebihan maka metode estimasi yang digunakan pada sistem persamaan simultan adalah 2SLS. Dalam sistem persamaan simultan data panel dinamis, masing-masing persamaan struktural merupakan persamaan regresi data panel dinamis dengan variabel eksogen. Salah satu variabel eksogen yang terdapat pada masing-masing persamaan struktural merupakan variabel endogen eksplanatori. Berikut adalah langkah-langkah estimasi parameter persamaan simultan data panel dinamis dengan 2 SLS :

1. Mengestimasi nilai dari variabel endogen melalui bentuk tereduksi menggunakan GMM Arellano-Bond.

2. Mengestimasi persamaan struktural dengan mensubtitusi variabel endogen pada sisi kanan dengan estimasi variabel endogen yang telah didapatkan pada langkah 1 menggunakan GMM Arellano-Bond. 
Dengan demikian, rangkaian metode estimasi ini kemudian dinamakan Two Stage Least Square Generalized M ethod of Moment A rellano and Bond (2SLS GMM AB).

\section{Hasil Penelitian}

\section{Persamaan Struktural Indikator Pertumbuhan Ekonomi}

Hasil pengolahan data menggunakan stata diringkas di dalam tabel 1 sebagai berikut :

Tabel 2. Hasil Estimasi Persamaan Struktural Pertumbuhan (PDRB) Ekonomi dengan 2 SLS GMM-AB

\begin{tabular}{lcccccc}
\hline InPDRB & $\begin{array}{c}\text { Estimated } \\
\text { Coefficients }\end{array}$ & $S E$ & $Z$ & $P$-Value & $\begin{array}{c}\text { Short-run } \\
\text { Multiplier }\end{array}$ & $\begin{array}{c}\text { Long-run } \\
\text { Multiplier }\end{array}$ \\
\hline $\operatorname{InPDRB} \mathrm{t}_{-1}$ & 0,2442 & 0,0181 & 13,52 & 0,000 & & \\
\hline $\operatorname{InOP}$ & 0,0097 & 0,0018 & 5,39 & 0,000 & 0,0097 & 0,0128 \\
\hline $\operatorname{InTDGE}$ & 0,0388 & 0,0069 & 5,58 & 0,000 & 0,0388 & 0,0513 \\
\hline $\operatorname{InEM}$ & $-0,4651$ & 0,0223 & $-20,83$ & 0,000 & $-0,4651$ & $-0,6154$ \\
\hline
\end{tabular}

Sumber : O utput Stata (diolah)

Berdasarkan Tabel 2 diperlihatkan bahwa koefisien lag indikator pertumbuhan ekonomi $\left(\right.$ PDRB $_{\mathrm{t}-1}$ ) berpengaruh positif dan signifikan secara statistik. Dengan demikian, setiap provinsi-provinsi di Indonesia dapat mengambil kebijakan makroekonomi yang tepat dengan backward looking dalam pencapaian pertumbuhan ekonomi yang tinggi dan berkelanjutan. Nilai ekspor (OP) berpengaruh signifikan terhadap pertumbuhan ekonomi (PDRB). A pabila terjadi peningkatan ekspor (OP) sebesar $1 \%$ maka secara jangka pendek akan menyebabkan peningkatan pertumbuhan ekonomi sebesar $0,0097 \%$ dan secara jangka panjang sebesar 0,0128\%. Hal ini sejalan dengan teori bahwa ekspor akan secara langsung memberi kenaikan penerimaan dalam pendapatan suatu negara. Terjadinya kenaikan penerimaan pendapatan suatu negara akan mengakibatkan terjadinya kenaikan tingkat PDB. Dengan kata lain ekspor akan menyebabkan pertumbuhan ekonomi.

Belanja langsung pemerintah (TDGE) berpengaruh secara signifikan terhadap pertumbuhan ekonomi (PDRB). A pabila terjadi peningkatan belanja langsung pemerintah (TDGE) sebesar $1 \%$ maka secara jangka pendek akan 
Penerapan 2 SLS GMM-AB pada Persamaan Simultan Data Panel Dinamis...

menyebabkan peningkatan pertumbuhan ekonomi sebesar 0,0388\% dan secara jangka panjang sebesar $0,0513 \%$. Secara teoritis hasil ini benar karena dalam perekonomian diperlukan peran pemerintah untuk melakukan berbagai jenis pembelanjaan. Salah satunya adalah belanja langsung. B elanja langsung itu sendiri digunakan untuk membiayai belanja pegawai (gaji PNS, polri, TNI, dII), pembangunan dan memperbaiki infrastruktur serta menyediakan fasilitas pendidikan dan kesehatan. A gar terwujud sasaran yang tepat dalam pembelanjaan maka pemerintah daerah melaksanakan suatu kebijakan fiskal dengan menyusun A PBD. Dengan alokasi belanja langsung yang proporsional dan dikelolanya APBD oleh pemerintah daerah masing-masing tanpa ada campur tangan pemerintah pusat dalam (otonomi daerah/ desentralisasi fiskal), pemerintah daerah lebih leluasa untuk menentukan prioritas pembangunan guna meningkatkan pertumbuhan ekonomi (PDRB) untuk menyejahterakan masyarakat di daerahnya.

Tingkat pengangguran (EM) secara simultan memberikan pengaruh signifikan terhadap pertumbuhan ekonomi (PDRB). A pabila terjadi peningkatan tingkat pengangguran (EM) sebesar 1\% maka secara jangka pendek akan menyebabkan perlambatan pertumbuhan ekonomi sebesar $0,4651 \%$ dan secara jangka panjang sebesar 0,6154\%. Hal ini senada dengan hukum Okun (1962) yang menyajikan dua hubungan empiris antara pengangguran dan output riil (pertumbuhan ekonomi).

\section{Persamaan Struktural Indikator Pengangguran (EM)}

Hasil pengolahan data menggunakan stata diringkas di dalam tabel 1 sebagai berikut :

Tabel 3. Hasil Estimasi Persamaan Struktural Indikator Tingkat Pengangguran (EM) dengan 2 SLS GM M -AB

\begin{tabular}{lcccccc}
\hline \multicolumn{1}{c}{ InEM } & Est Coef & $S E$ & $Z$ & P-Value & $\begin{array}{c}\text { Short-run } \\
\text { Multiplier }\end{array}$ & $\begin{array}{c}\text { Long-run } \\
\text { Multiplier }\end{array}$ \\
\hline $\operatorname{InEM~t-1~}$ & 0,0322 & 0,2024 & 0,1600 & 0,8740 & & \\
\hline $\operatorname{InDDI}$ & $-0,0002$ & 0,0069 & $-0,0300$ & 0,9760 & $-0,0002$ & $-0,0002$ \\
\hline $\operatorname{InTDGE}$ & 0,0487 & 0,0648 & 0,7500 & 0,4520 & 0,0487 & 0,0503 \\
\hline $\operatorname{InW}$ & $-0,3481$ & 0,1446 & $-2,4100$ & 0,0160 & $-0,3481$ & $-0,3597$ \\
\hline $\operatorname{InPDRB}$ & $-0,9562$ & 0,1716 & $-5,5700$ & 0,0000 & $-0,9562$ & $-0,9880$ \\
\hline
\end{tabular}

Sumber : Output Stata (diolah) 
Berdasarkan Tabel 3 diperlihatkan bahwa terdapat pengaruh negatif yang signifikan antara tingkat upah (W) terhadap pengangguran (EM). A pabila terjadi peningkatan tingkat upah (W) sebesar $1 \%$ maka secarajangka pendek akan menyebabkan penurunan tingkat pengangguran sebesar 0,3481\% dan secara jangka panjang sebesar 0,3597\%. Hal ini senada dengan Sukirno (2012) yang mengatakan bahwa dalam K urva Philips, garis lengkung menunjukkan hubungan negatif antara persentase perubahan tingkat upah dan pengangguran. Di samping itu pertumbuhan ekonomi (PDRB) berpengaruh secara simultan dan signifikan terhadap pengangguran (EM). A pabila terjadi peningkatan pertumbuhan ekonomi (PDRB) sebesar $1 \%$ maka secara jangka pendek akan menyebabkan penurunan tingkat pengangguran (EM) sebesar 0,9562\% dan secara jangka panjang sebesar 0,9880\%. Berdasarkan teori, antara pertumbuhan ekonomi dan tingkat memiliki hubungan negatif. \%. Hal ini senada dengan hukum Okun (1962) yang menyajikan dua hubungan empiris antara pengangguran dan output riil (pertumbuhan ekonomi) serta penelitian Indriani (2006) menghasilkan kesimpulan bahwa peningkatan pertumbuhan ekonomi akan menurunkan tingkat pengangguran.

\section{Persamaan Struktural Indikator Tingkat Kemiskinan}

Hasil pengolahan data menggunakan stata diringkas di dalam tabel 1 sebagai berikut:

Tabel 4. Hasil Estimasi Persamaan Struktural Indikator Tingkat Kemiskinan dengan 2 SLS GM M-A B

\begin{tabular}{lcccccc}
\hline InHC & Est Coeff & $S E$ & $Z$ & $P$-Value & $\begin{array}{c}\text { Short-run } \\
\text { Multiplier }\end{array}$ & $\begin{array}{c}\text { Long-run } \\
\text { Multiplier }\end{array}$ \\
\hline $\operatorname{InHCt}-1$ & 0,5759 & 0,1074 & 5,3600 & 0,0000 & & \\
\hline $\operatorname{InIG}$ & 0,2756 & 0,0921 & 2,9900 & 0,0030 & 0,2756 & 0,6498 \\
\hline $\operatorname{InIHK}$ & 0,0123 & 0,0060 & 2,0600 & 0,0390 & 0,0123 & 0,0290 \\
\hline $\operatorname{InPDRB}$ & $-0,4194$ & 0,0627 & $-6,6900$ & 0,0000 & $-0,4194$ & $-0,9887$ \\
\hline
\end{tabular}

Sumber : O utput Stata (diolah)

Berdasarkan Tabel 4 diperlihatkan bahwa koefisien lag indikator kemiskinan (HC) berpengaruh positif dan signifikan secara statistik pada taraf nyata 5\%. Indeks gini (IG) juga berpengaruh signifikan terhadap kemiskinan. A pabila terjadi peningkatan Indeks gini (IG) sebesar $1 \%$ maka 
Penerapan 2 SLS GMM-AB pada Persamaan Simultan Data Panel Dinamis...

secara jangka pendek akan menyebabkan kenaikan kemiskinan (HC) sebesar $0,2756 \%$ dan secara jangka panjang sebesar $0,6498 \%$. Hasil ini sesuai teori bahwa semakin besar ketimpangan distribusi pendapatan atau kesenjangan ekonomi maka akan meningkatkan kemiskinan. Di samping itu, Indeks Harga K onsumen (IHK) sebagai indikator inflasi juga berpengaruh secara positif dan signifikan terhadap kemiskinan. A pabila terjadi peningkatan Indeks $\mathrm{H}$ arga K onsumen (IHK) sebesar 1\% maka secara jangka pendek akan menyebabkan kenaikan kemiskinan ( $\mathrm{HC}$ ) sebesar $0,0123 \%$ dan secara jangka panjang sebesar $0,0290 \%$. Hasil ini juga sesuai teori bahwa apabila terjadi inflasi (kenaikan harga barang) akan mengakibatkan menurunnya daya beli masyarakat. Daya beli masyarakat yang menurun tidak menutup kemungkinan akan berakibat pada tidak terpenuhinya kebutuhan hidup. Kondisi ketidakmampuan dalam memenuhi kebutuhan hidup disebut dengan kemiskinan.

Pertumbuhan ekonomi (PDRB) berpengaruh signifikan terhadap kemiskinan $(\mathrm{HC})$ pada taraf nyata $5 \%$. A pabila terjadi peningkatan pertumbuhan ekonomi (PDRB) sebesar 1\% maka secara jangka pendek akan menyebabkan penurunan kemiskinan (HC) sebesar 0,4194\% dan secara jangka panjang sebesar $0,9887 \%$. Dengan demikian pemerintah diharapkan melakukan berbagai upaya untuk mewujudkan pertumbuhan ekonomi yang berkualitas demi mengeluarkan penduduk miskin dari jurang kemiskinan.

\section{Penutup}

Model regresi data panel dinamis banyak ditemui dalam persamaan ekonomi dimana terdapat variabel endogen eksplanatori yaitu lag variabel dependen berkorelasi dengan error. $\mathrm{Hal}$ ini menyebabkan estimasi OLS pada regresi data panel dinamis menghasilkan penduga koefisien yang bias dan tidak konsisten. Untuk mengatasi permasalahan tersebut, Penerapan Generalized M ethod of M oments A rellano and Bond (GM M -A B) pada model regresi data panel dinamis menghasilkan penduga koefisien yang tak bias, konsisten dan efisien.

Penerapan estimasi 2 SLS GMM-AB pada analisis perekonomian Indonesia menunjukkan bahwa pertumbuhan ekonomi di Indonesia secara signifikan dipengaruhi oleh pertumbuhan ekonomi tahun sebelumnya ( $\mathrm{L}$ ag 
satu pertumbuhan ekonomi) dan tiga variabel bebas yaitu ekspor, belanja langsung pemerintah, dan pengangguran. Peningkatan ekspor sebesar $1 \%$ secara jangka pendek akan menyebabkan peningkatan pertumbuhan ekonomi sebesar 0,0097\% dan secara jangka panjang sebesar 0,0128\%. A pabila terjadi peningkatan belanja langsung pemerintah sebesar $1 \%$ maka secara jangka pendek akan menyebabkan peningkatan pertumbuhan ekonomi sebesar 0,0388\% dan secara jangka panjang sebesar 0,0513\%. Di sisi lain peningkatan tingkat pengangguran sebesar $1 \%$ secara jangka pendek akan menyebabkan perlambatan pertumbuhan ekonomi sebesar 0,4651\% dan secara jangka panjang sebesar $0,6154 \%$. Pertumbuhan ekonomi mempunyai pengaruh negatif dan simultan secara signifikan terhadap pengangguran.

\section{Daftar pustaka}

AI Dakhil, K. I. 1998. "A M ethod for Estimating Simultaneous Equations Models with Time Series and Cross-section Data, J. King Saud Univ, Vol.10, hal.13-28.

A nderson, T. W., dan Hsiao, C. 1982. "Formulation And Estimation of Dynamic Models Using Panel Data", Journal of Economic, hal.4782.

A nwar. S., dan N guyen, L. P. 2010. "Foreign Direct Investment and Economic Growth in Vietnam", A sia Pasific Business Riview, Vol. 68, hal.527.

A rellano, M., dan Bond, S. 1991. "Some Test of Specification for Panel Data : M onte Carlo Evidence and an Application to Employment Equations", The Review of Economic Studies, Vol.58, hal.277297.

Baltagi, B. H. 2005. Econometric A nalysis of Panel Data, New York: John Wiley dan Sons.

Bond, S., dan Blundell, R. 1995)," Initial Conditions and M oment Restriction in Dynamic Data Models", Journal of Econometrics, Vol.87, hal.115-143

Greene, W. H. 1990. Econometrics A nalysis, USA : Collinier Macmillan Canada Inc.

Gujarati, D. 2000. Econometrics A nalysis, New Jersey: Prentice Hall.

Hapsoro, D. N. Y., dan Gunanto. 2013. "A nalisis Pengaruh Variabel Ekonomi makro Regional Terhadap Tingkat Kemiskinan Perkotaan", 
Diponegoro Journal Of Economics, 2, 1-12

Hsiao, C. 2003. A nalysis of Panael Data. New York : Cambridge University Press.

Indriani, R. 2006. Pengaruh Pertumbuhan Ekonomi Terhadap Pengangguran di Indonesia, Tugas Akhir, FE Universitas Katolik Indonesia A tmajaya.

Iswanto, D. A. 2013. "Pertumbuhan Ekonomi dan Pengangguran : Validitas Hukum Okun di Indonesia", Jurnal IImiah , 1-14.

Jonaidi, A. 2012. "A nalisis Pertumbuhan Ekonomi dan Kemiskinan", Jurnal Kajian Ekonomi , 1, 140.

K resnandra, A. A. N. A \& Erawati N. M . A. E. 2013. "Pengaruh Pajak Daerah dan Retribusi Daerah Terhadap Tingkat Pengangguran Dengan Belanja Modal Sebagai Variabel Pemoderasi", E-Jurnal A kuntansi U niversitas U dayana, 5.3, 544-560.

K usumaningsih, W. 2009. A nalisis Faktor-Faktor yang M empengaruhi Kondisi PDRB Kabupaten/ Kota di Provinsi Jawa Tengah, Tugas A khir, Universitas Negeri Sebelas M aret Surakarta.

Lai, T. L, Small, D.S dan Liu, J., (2008. "Statistical Inference in Dynamic Panel Data Models", Journal of Statistical Planning and Inference, Vol.138, hal.2763-2776.

Lubis, K. A ., \& Setiawan. 2013. "Penerapan Generalized M ethod Of M oments Pada Persamaan Simultan Panel Dinamis Untuk Pemodelan Pertumbuhan Ekonomi di Indonesia", Prosiding Seminar Nasional M anajemen Teknologi XIX (hal. A-3-1 s.d A.3.8). Surabaya: Proram Studi M M T-ITS.

M ankiw, N. G. 2010). Macroeconomic (7 ed.). New York: Worth.

M erizal, Y. 2008. A nalisis Pengaruh Pendidikan, Tingkat U pah M inimum Kabupaten, dan K esempatan Kerja Terhadap Pengangguran Terdidik di Kab Semarang, Tugas A khir, Universitas Diponegoro Semarang.

M ustaqim. 2009. Pendekatan Persamaan Simultan dengan Fixed Effect M odel untuk Pemodelan Penyerapan Tenaga Kerja di Jawa Tengah, Tesis, Institut Teknologi Sepuluh Nopember Surabaya.

Nismawati, B. 2010. Penaksiran Parameter Pada Model Panel Data Dinamis M enggunakan M etode A rellano dan B ond, Tugas A khir, U niversitas Indonesia.

Setiawan, dan Kusrini, D. E. 2010. Ekonometrika, Yogyakarta: C.V A ndi Offset. 
Sseddighi, L., dan Katos. 2000. Econometrics A Practical A pproch,L ondon: Routledge.

Sukirno, S. 2012. Ekonomi Makro Teori Pengantar, Jakarta: Rajawali Pers. 